\title{
The Interrelationship between Literary Translation and Literary Criticism: Reading in Interpretive Traditions
}

\section{Abstract}

As a literary work is reviewed or commented on by a large corpus of critical approaches, stratified lines of interpretation may take shape, which try to appropriate the work in question. This condition can have significant implications for literary translation. The translator's subjective decisions situate the translation in a matrix of relations with critical readings. This study addresses the theoretical and methodical aspects of the interaction between literary criticism and literary translation by focusing on the historicity of the literary work. The study argues that an interpretive tradition is gradually and cumulatively shaped in the form of metatexts with compatible philosophies. As a result, a literary work may be interpreted according to various traditionalized readings. The study incorporates elements of transtextuality (intertext and metatext) with the temporality-related postulates of hermeneutics, suggesting a holistic analysis method.

Keywords: narrative, literary translation, traditionality, historical continuity, Hafez's poetry

\section{Introduction}

Many theoretical frameworks have tried to tackle the problem of literary interpretation and crosscultural reception (see Bassnett and Bush; García). How a translator interprets a text, along with the factors influencing his/her mental processes, is among the central issues addressed in interpretive theories of translation (see Stolze), especially literary translation (Hüsgen; see also Kohlmayer). Literature is usually characterized by low referentiality, personal subjectivity, and idiosyncratic formal style. Complicated world-making techniques, which integrate disparate 
elements into a possible whole, create diversified networks of signification that may move beyond individual/communal conventionalized range of experience. Although perceived as innovative entities in their own organic context, literary texts may appear to be even more exotic to readers across different cultures and societies (see Bassnett, Translation).

Yet, what appears to be missing from the speculations on literary translation is a conceptual discipline that can account for the continuity and stratification of the lines of reading in literary interpretation. It is axiomatic that a literary work, no matter how outlandish it may be, arises from a socio-historical milieu, and that it is ultimately recontextualized in a receiving foreign culture as a result of translation (Bassnett, Translation); but how is it that the work in question is associated with or read within a particular frame of understanding? What are the elements that direct readers toward a specific interpretation of the text? Is a translation itself a continuation of the given reading of the text, or is it fully innovative and free-standing?

Developments in literary theory over the second half of the 20th century revealed complicated modes of textuality that connect texts to each other. Gérard Genette's notion of transtextuality involves several textual modes that somehow surround a given text in particular ways. Metatexts and intertexts are particularly interesting as they are shaped through historical consciousness and a sense of continuity. A critical metatext, as a form of literary criticism, is a literary production which comments on, evaluates, or sometimes explicates an original literary artwork. An exploration of the philosophical, social, and ideological aspects of a group of metatexts dealing with the same literary work may reveal that these metatexts are connected to each other in meaningful ways, regardless of authorial intention. They may even establish strong traditions over time. To make this understanding possible, however, theories of textuality must be inspected from a hermeneutic perspective.

The major purpose of this study is to explore the interrelationship between literary criticism and literary translation with reference to the hermeneutic notion of interpretive tradition. The main postulate of the study is that literary works, as a result of extensive literary criticism, are situated in stratified lines of reading that may form interpretive traditions. The study further investigates how translators respond to interpretive traditions, or how their works may be situated in a given tradition in the context of literary criticism. The work of a translator may be compatible with a particular 
tradition, integrate several traditions, or create a new reading. The study substantially relies on the hermeneutic exploration of historicity, especially Gadamer's discussion of the "temporality of a work of art" (Truth and Method 120). To provide an actual sample of the framework used, the study shows how English translations of a ghazel in The Divan of Hafez represent different interpretive traditions, irrespective of the translators' intentions.

\section{Metatextuality, Literary Criticism, and Interpretive Traditions}

Before the idea of an interpretive tradition can be fully framed in this study, we should first explore how the mechanism of textuality works in a tradition. More specifically, we need to figure out how texts within a corpus are connected to each other, and how they contour a larger narrative (a macro-narrative) about a particular work of literature. Meanwhile, one has to take into account one of the most serious aspects of literary criticism: the critical scheme of interpretation and evaluation. As a result, an interpretive tradition in its most rudimentary configuration involves an assemblage of critical or expository texts about a singular literary work.

To explain how this textual process takes place, we need to incorporate the distinctive features of literary criticism into a general theoretical notion. In his exploration of textual interrelations in literary productions, the French literary theorist Gérard Genette proposed several innovative notions. Genette's work focuses on semiotics and is associated with structuralism. The central topic he explores in his theory is the connectedness of literary works through transtextuality: "the subject of poetics is transtextuality, or the textual transcendence of the text, which I have already defined roughly as 'all that sets the text in relationship, whether obvious or concealed, with other texts"' (1). Transtextual relationships can be broken into five categories: intertextuality (the actual presence of one text within another), paratextuality (elements inside or attached to the text such as titles, subtitles, prefaces, forewords, etc.), metatextuality (an association between texts through commentary or criticism), hypertextuality (the reconfiguration of one work in another as in adaptation), and architextuality (signals that specify the genre of a text).

An important issue about transtextual relations is that they, depending on their context, may be interrelated. For instance, "[t]he critical metatext can be conceived of, but is hardly ever practiced, without the often considerable use of a quotational intertext as support" (Genette 8). From the 
perspective of the present study, however, regardless of the ambiguities in the above typology, metatextuality can best serve critical, expository, or evaluative relationships. The basic functioning of literary criticism must be associated with metatextual processes. Another important issue is that although Genette makes room for implicit metatextual relations, the type of criticism considered in this study is admittedly explicit; as a result, it is called "critical metatext."

Yet, what are the elements of a critical reading as a metatext? To answer this question, one has to delve into the history of literary criticism (see Kennedy), trying to identify how a critical text approaches a literary work. A foundational principle in literary criticism is the philosophical ground on which criticism rests. As Habib truthfully states, "[a] great deal of literary theory presupposes familiarity with a broad range of philosophical ideas" (2). Meanwhile, it must be emphasized that a metatext is not bound to the realm of abstract thinking. Since the 19th century, many attempts have been made to codify literary knowledge and develop it into a well framed academic discipline. As a result of these attempts, literary practices have been characterized by "professionalisation and specialisation [sic]" (Atherton 4-6). Such characteristics could in turn underscore the social agency that producers of literature-related works, including literary critics, can represent. Another aspect of critical metatexts is that they are not "neutral"; a serious question is how certain works in a nation's literature occupy a more central position compared with others. For instance, addressing the notions of centrality and marginality, Kolbas claims that "orthodox literary criticism ... has implicitly favored canonical over non-canonical works" (3).

The philosophical, social, and ideological specifications of literary criticism, along with any other regulative re-reading such as commentaries, highlight the complexity of this practice and the impact that it may have on the way a literary work is interpreted. An interesting issue is how a metatext can influence the readings of a given literary text in other modes of practical interpretation such as translation. Does a literary translation reflect a conventional or peculiar way of understanding a literary text? Does a metatext exist on its own or may establish intertextual relations with other metatexts?

Genette's notion of transtextuality, along with its subtypes, is partially faithful to structuralist underpinnings. Nonetheless, Genette's theoretical notions move beyond mere ahistorical, elementby-element analyses, mostly because among the five transtextual types, intertextuality and 
metatextuality can only be conceived of when a temporal continuum is envisaged. Yet, what remains to be perceived is the nature of this communication, especially as it takes place outside of the synchronic structural frame. To be theoretically enhanced, then, the notion of metatext has to be revisited in the light of another school of continental philosophy.

From the perspective of this study, a complication of critical approaches (metatexts) with compatible philosophical, social/academic, and ideological foundations constitutes a "tradition" that decides the meaning and axiological dimensions of a literary work. To make this understanding possible, one needs to draw on a more complicated discipline of interpretation in which intersubjective relations can be postulated. Hermeneutics, broadly defined, is the philosophy of interpretation. Although it shares certain theoretical principles with structuralism (the conventionality of meaning in particular), hermeneutics is critical of many structuralist assumptions. The notion of historicity and the way human perception is entangled with a sense of temporal movement are among the underlying concerns of hermeneutic thinkers (such as Heidegger, Gadamer, and Ricoeur).

To understand the collection of several metatexts as streams of an interpretive tradition, we should first realize how tradition is conceptualized in hermeneutics. The notion, of course, is considerably different from the conventional sense of the word, which is usually perceived as a historically inferior, monolithic period of elapsed time. On the contrary, the past is seen as a dynamically interpreted entity which is in constant connectivity with the present and the future. Hans-Georg Gadamer has profoundly explored the notion of traditionality in his philosophy, specifying its various dimensions. Prejudice, a technical and rather controversial concept in Gadamer's hermeneutics, addresses the situated-ness and historicity of interpretation. In an introduction to Gadamer's Philosophical Hermeneutics, David E. Linge states:

For Gadamer, the past has a truly pervasive power in the phenomenon of understanding ... The role of the past cannot be restricted merely to supplying the texts or events that make up the "objects" of interpretation. As prejudice and tradition, the past also defines the ground the interpreter himself occupies when he understands (XV). 
The significance of historicity, as a fluid and accumulative process, suggests that the knowledge/experience of past events consists in a practical function, or what is called "effective history" (Wirkungsgeschichte) by Gadamer; according to this concept, "no understanding would be possible if the interpreter were not also part of the historical continuum which he and the phenomenon he studies must share" (Mueller-Vollmer 256). It must be noted that effective historical consciousness is not a free-standing variable and is constrained by a major condition. In response to the problem of multiple understandings and interpretation relativity, Gadamer emphasizes the principle of practicality. Explicating this criterion, Dostal explains: "[p]ractical application is not, on Gadamer's account, an external, after the fact, use of understanding that is somehow independent of the understanding. All understanding is practical" (3). An interpretive tradition, then, consists of one or several significant metatexts that try to make an understanding possible, usually by appropriating and legitimating it. When an interpreter situates a text within a lager narrative, s/he seeks to discern how the elements in the text (including single words) are interpreted. In the realm of translation, the notion of interpretive traditions can significantly contribute to a systematic evaluation of literary translation. The following sub-section is concerned with interpretive traditions in literary translation.

\section{Interpretive Traditions in Literary Translation}

To investigate how translators respond to interpretive traditions, or how their works may be situated in a given tradition (regardless of their intention), we should primarily focus on translation in the context of literary criticism. In a recent study, Bassnett has probed into the relationship between literary criticism and literary translation. As a major figure associated with the cultural turn in translation studies, Bassnett endeavors to underscore the significance of literary translation as a developing field with appreciated socio-historical effects in the 20th century (and, of course, throughout history). Meanwhile, she criticizes the mindset of literary academics who have ignored the visible influence and functions of translation (Bassnett, "The Figure" 300-03). What is important in her observation, from the viewpoint of interpretive traditions, is the constant interplay between literary reservoirs in a given language, literary criticism, and the mediatory functions of translation. 
To emphasize the dialectical nature of debates exchanged among literary critics, Bassnett revisits the controversy between Matthew Arnold (1822-1888) and Francis Newman (1805-1897) over the latter's translation of The Iliad by Homer. Apart from the nature of the conflicts that fueled the debate, one should consider the horizons of understanding or "readings" that try to appropriate the representation of The lliad in English. The controversy, as a telling example, revolves around two metatexts or critical readings that decide the axiological dimensions of literary translation.

Although Bassnett, like the majority of literary scholars, does not suggest any systematic framework to lucidly depict the mechanisms behind such debates, hermeneutic theories can provide a better picture. The major purpose of this study, as already mentioned, is to explore the interrelationship between literary criticism and literary translation. To explain such an interrelationship, we need to consider the unstable space in which mainstream readings or metatexts of a literary work are distinguished and influence each other. A highly significant metatext or an incorporation of metatexts may shape an interpretive tradition that decides how the work in question must be read. In this section, the factor of translation is added to the whole process.

Hermeneutic translation theories have long explored factors such as subjectivity, multivocality, uncertainty, and conflict of interpretations. Two recently proposed theories are translational hermeneutics (Cercel et al.) and Ricoeur's translation theory (Kharmandar, "Ricoeur's Extended Hermeneutic Translation Theory"). These theoretical streams have both addressed historicity and one of its major by-products, traditionality, in translation. In the first unified version of translational hermeneutics, Cercel et al. enumerated the principles of interpretation. In their discussion, which is inspired by the theories of such thinkers as Schleiermacher, Heidegger, Gadamer, Eco, and Ricoeur, Cercel et al. explore subjective, historical, phenomenological, processual, holistic, and reflective dimensions of translation (25-28).

Mentioning some characteristics of historicity, they state that "[h]uman languages develop constantly. Persons are not static objects, but change continuously in their interactions in a community and within their general culture. The objects of research in the humanities are objects developed over time" (Cercel et al. 25). They also emphasize Gadamer's notion of tradition in the formation of human communities. The other related study investigates historical movement and 
textuality through Ricoeur's narrative theory (Ricoeur, Time and Narrative) and his contemplation of memory and forgetting (Ricoeur, Memory, History, Forgetting):

[The] memory-forgetting pattern, as represented by narratives, can be in part explained by the functioning of traditionality: a dynamic pattern of tradition-versus-innovation as "internalized interaction." This quest would help explore how meaning is decided in traditions (regardless of authorial intention) and to what extent new narratives (as criticisms, statements, literary works, or translations) strengthen or violate accumulated historical memory (Kharmandar, "Ricoeur's Extended" 87).

Both literary criticism and literary translation can strengthen or violate historical memory although a translation may or may not pursue the line of interpretation in the existing metatexts. In other words, the working of a translator, as a social agent, may lead to new readings while creating innovative horizons of understanding. Does this suggest that a translation itself can be a metatext? Emphasizing that any translation of a literary text is an interpreted version of the text, Fitch tries to figure out how translation, text, and metatext may be related. Fitch's discussion, however, fails to make a definitive conclusion, although it reveals that translation could be seen as a process including paraphrase and quotation (27).

Although reconceptualization and reformulation necessarily occur in (literary) translation, it would be very difficult to assign the "critical" characteristic of metatext to translation. As a result, there are borders that roughly distinguish translation and criticism in an interpretive tradition ${ }^{[1]}$ Following the theoretical concerns in the previous sections, the next section reports an actual application of interpretive tradition and literary translation.

\section{Reflections of Hafez in Translation}

Hafez (Hafiz) of Shiraz (14th century AD) is regarded as one of the greatest Persian poets with international fame. It is unanimously believed that his Divan (a collection of poems) constitutes the canonical foundations of Persian ghazel (an Arabic and Persian poetic scheme comparable to sonnet/ode). It would be extremely difficult, even if possible, to collect all pieces of the corpus written about his work. In Iran, there is a field of investigation that could be translated as "Hafez 
Studies" in English. One of the purposes of this field is to systematize the writings about Hafez and The Divan.

The huge diversity of criticisms and commentaries devoted to The Divan has led to the formation of various metatexts that seek to decipher the poet's message (see below). There has been a heated debate over some of Hafez's notions and their implications. Although categorizing all of these readings appears to be an insurmountable challenge, some major critics of The Divan have explicitly or implicitly traced the existence of interpretive traditions that have put The Divan into their respective schemes of understanding. Most obviously, the trail of these readings could be found in international translations of the book.

Proposing a categorization of The Divan interpretive traditions, Shamisa, an Iranian literary critic, has numerated three major lines of interpretation: mystical, Khayyamian, and historical-political (28-29). The mystical tradition, which is the oldest one, involves a creative interpretation of mystical and religious themes, which are usually rooted in Ancient Persian and Indian belief systems (Shamisa 31). A specification of Islamic mysticism lies in its individualism and shapelessness, as it is not governed by any universal framework (Sattari 12-39).

The Khayyamian tradition seems to be a contemporary reading (by modern writers/critics such as Sadegh Hedayat [1903-1951] and Ahmad Shamlou [1925-2000]). This tradition finds an intertextual relationship between Khayyam's poetry and that of Hafez. As Dargahi explains, the proponents of this reading believe The Divan, at least in part, is a reaction to deterministic aspects of life (e.g. hardship, frustration, and the finitude of human life), by suggesting hedonistic remedies (235-38). The historical-political tradition concentrates on The Divan as a historical sample of the period in which Hafez lived. In his book Hafez and Iran's Survival, Jafari-Langroudi basically concentrates on historical events and facts in the work of Hafez (such as Mongols' period) (33).

This is not, however, the only categorization of the readings explicating The Divan. In his voluminous book on Hafez, Estelami, another Iranian literary critic, suggests an implicit categorization in his reading of individual ghazels (or sometimes individual lines). According to this construal, there are romantic, mystical, and anti-hypocritical traditions that govern the interpretation of The Divan (Estelami 79-90) although, unlike Shamisa, Estelami does not exemplify the followers 
of each tradition. Instead, he mainly relies on the lines and their themes per se. It must be noted that, in popular belief, the majority of the ghazels are considered to be romantic.

From the perspective of translation, metatexts can be used to find how a literary translation situates itself in a particular tradition. Adherence to a particular reading may not appear as a clear statement in a critic's or translator's work. As already mentioned, hermeneutics is not bound to authorial intention, while it basically focuses on textual/semiotic entities and their interrelations. In light of the interpretive traditions explicating The Divan, one can analyze how the collection of signs, symbols, and values in the ghazels may be transformed into a particular reading. Let us take a look at some English translations of the first ghazel in The Divan:

Ho, saki, haste, the beaker bring,

Fill up, and pass it round the ring;

Love seemed at first an easy thing-

But ah! The hard awakening.

So sweet perfume the morning air

Did lately from her tresses bear,

Her twisted, musk-diffusing hair-

What heart's calamity was there

3

Within life's caravanserai

What brief security have I,

When momently the bell doth cry,

"Bind on your loads; the hour is nigh!"

Let wine upon the prayer-mat flow, 
An if the taverner bids so;

Whose wont is on this road to go

Its ways and manners well doth know.

5

Mark now the mad career of me,

From wilfulness to infamy;

Yet how conceal that mystery

Whereof men make festivity?

6

A mountain sea, moon clouded o'er,

And nigh the whirlpool's awful roar-

How can they know our labour sore

Who pass light-burthened on the shore?

7

Hafiz, if thou wouldst win her grace,

Be never absent from thy place;

When thou dost see the well-loved face,

Be lost at last to time and space. Arberry (83-4)

Arberry is a prolific author/translator of Islamic works. The above translation demonstrates his expertise in Arabesque and Persian symbolism. The ghazel is the prelude to The Divan and one of the essences of Hafez's poetry. Despite the imagery in the poem, it is normally read as a ghazel with mystical implications. Estelami, for instance, highlights that the lines suggest a mystical atmosphere (77). The imagery portrays an arduous journey that starts from a sweet and seemingly naïve love to horrifying whirlpools that can consume a follower's faith. The question is which interpretive tradition is represented in the translation. 
Considering the multivocal texture of Hafez's poetry, the translation appears to be a romantic one, even a specimen of Romanticism. "Romantic" in various poems of Hafez refers to symbols associated with love and pleasure (e.g. gardens, wine, roses, perfumes), a sense of femininity (e.g. dark eyelashes, ruby lips), and expressions of sorrow over loss (as in the long poem Wild Deer attributed to Hafez). In the ghazel under study, one of the sources of ambiguity arises from the lack of feminine/masculine pronominal structure in Persian. Yet, a reinforced feminine presence in the translation (sweet perfume, her tresses, her grace, well-loved face), emotional disturbance (mad career of me, infamy, moon clouded, whirlpool's awful roar, labour sore), and romantic ornaments ( wine, taverner), collectively situate the poem in a romantic reading, as specified in the metatexts.

Likewise, an international reader familiar with Romanticism may associate the poem with works such as Goethe's The Sorrows of Young Werther although the horizon of the readership at an international level would be extremely challenging to delineate. The romantic atmosphere in The Divan may appear in different forms in different ghazels, but it generally swings from bursts of passionate emotion to laments over lost love. Ghazel 1, if it is seen as a romantic expression, depicts a condensed narrative of sweetness leading to emotional turmoil. The romantic reading exhibits itself right from the start in Shahriari's version (line 1), although the story ends in a state of devotion: "O beautiful wine-bearer, bring forth the cup and put it to my lips, / Path of love seemed easy at first, what came was many hardships."

Other elements strengthen the primary romantic reading: beautiful locks, dark ringlets, my own path of love. However, the sequence of events, following a twist (pilgrimage, dark midnight, the tempestuous whirlpool), reveals the reality of earthly love to the speaker (now I am in bad repute), as a result of which he finds Divinity (His presence, Stick to the One you know, let go of imaginary trips). The structure of the narrative is framed as follows:

"Passionate but insufficient earthly love Twist of emotion Finding Divinity"

The above translation is a perfect example of a reading that integrates mainstream traditions (romantic and mystical), but is it necessarily a major "conceptual" innovation? There are already versions of such narrative patterns in Persian literature. For instance, in Farid Ud-Din Attar's The Conference of the Birds, there is a story about a man called sheik of San'an and a Christian girl, 
which relatively follows the structural pattern found in the above translation. In the poem Wild Deer, which is usually published as an attachment to some of The Divan versions, the beloved is characterized as a fleeting, mysterious deer. Trying to join her, the speaker goes through several stages of hardship by embarking on a long journey. The poem concludes in a number of witty remarks, but, interestingly, it again expresses a sense of disappointment in earthly love and finds solace in the Houris (heavenly women usually translated as angles in English). Therefore, although the poem may represent an integrated version, it does not suggest a new theme.

Contrary to the above representations, Clarke's version published in 1891 quite impressively conceals the (possible) romantic reading and foregrounds images that can more or less illustrate an ascetic ambiance in the poem. First, he avoids the problem of pronoun use altogether in the second line:

By reason of the perfume of the [her?] musk-pod, that, at the end, the breeze displayeth, from that

$$
\text { [her?] fore-lock, }
$$

From the twist of its [her?] musky curl, what blood befell the hearts!

Other images too contribute to a religious devotion narrative throughout the poem: chattels of existence, Magians, holy traveler, presence from Him, abandon the world. The central term the Beloved can be perfectly associated with Divine Love as perceived in Abrahamic religions. This depiction roughly fits into the mystical reading traditionalized by the readers of Hafez. In the 1875 version, Bicknell uses paratextual rewriting through glossing the English terms in footnotes (4-5). This translation again portrays a mystical movement with a sense of yearning (rather than lovesickness): the pod's aroma, our hearts, Magian, the traveller [sic] of the Pathway, From Him, Bid to the world a last farewell. There is no sense of wine-drinking or exhibited feminine image in the translation. In another representation, Avery and Heath-Stubbs start their translation with a paratextual note which provides an encapsulated version of the poem:

He tells of the difficulties of love's way. The experienced guide knows that we must abandon reason to traverse its stages. Love begins with desire for self-gravitation, and leads to ignominy. But by continual preservice that may be attained for which the world is well lost. (19) 
The translators avoid any romantic expression, as the wine-bearer or Saki is simply called Boy in their version. Like Clarke and Bicknell, they avoid any feminine reference in line 2, while using "his presence" in the last line. Again, this representation emphasizes a mode of devotion rather than a romantic one. As expected, none of the translations involved historical/political references although there is a slight anti-hypocritical sense in line 5, which suggests Divine Love cannot be achieved through selfishness. Line 1 also implies a Khayyamian conviction (a sense of loss to be cured by wine) but further part-whole cross-referencing conveys a romantic or mystical reading.

The stratification of the readings, of course, is accompanied by tension and denial. For instance, Dargahi rules out the basis of the mystical or Sufistic approaches despite the large corpus of writings advocating such readings. Narrative selectivity may bring about more serious consequences in translations because they "represent" the original, while the majority of foreign readers may not have access to the resources that could validate their understanding. In his deconstructive exploration of poetry translation, García observes that, "in shaping the target text, which is bound to the interpretational framework of the target culture, the translator gives rise to a new exegetic infinite." (116). This condition can be seen in the English translations in which a semiotic entity such as saghi (Saki, line 1) is rendered as "O beautiful wine-bearer" (Shahriari) in one translation and "Boy" (Avery and Heath-Stubbs) in another. These choices create very remote narrative worlds, implying that literary translation criticism can be a highly dynamic, variegated, and even controversial field, which deserves more consideration on the part of literary critics and literary historiographers.

\section{Concluding Remarks}

Literary traditions, especially as far as canonical works of literature are concerned, are normally constituted by a collection of approaches that share philosophical foundations and thematic arrangements. As a result of the incorporation of such approaches, a literary tradition is configured. Metanarratives, in the form of traditions, decide the axiological content of literary works. They try to explain how literary production can be interpreted and how wide its range of postulates is. This study focused on the interaction of literary translation and literary criticism. An interpretive tradition is composed of one or several critical approaches that share philosophical, social, and ideological 
foundations. A tradition is a composite of metatexts connected to each other over time. A translator is regarded as an active agent in making decisions about the axiological dimensions of a literary work and how it may be situated in a particular tradition. Additionally, metatexts that formulate a tradition can have practical implications for evaluators of literary translation. Specifying the backgrounds of a translation or how it could be intertextually associated with one or several metatexts can considerably simplify the process of decision-making for evaluators. The chain of texts and their affiliations can readily help literary translation critics to approach a translation. The affiliations, of course, can have socio-cultural implications as they suggest the existence of a form of stratification in meaning interpretation (Kharmandar, "The Strata").

An interpretive tradition represents a holistic entity which encompasses both minimal and maximal elements of textuality. The meaning of an item (such as a sign, a symbol, a single word) is decided through a measure of interaction that the item has with the entirety of the items that are perceived to influence it. A fundamental problem, however, is that one cannot decide the range of the influence with absolute certainty. The dynamics of understanding, in fact, involves the interplay of several factors that together shape a whole, although most of the factors remain in the background. In translational hermeneutics, the schemata decided by the historical situation, communal conventions, and personal improvement are taken into account as forces that shape meaning (Cercel et al.). These factors, however, do not appear inside the text; they surround it, while their inclusion or exclusion depends on narrative selectivity (Kharmandar "Ricoeur's Extended").

To provide an example of analysis, the study considered several English translations of a ghazel of Hafez. The review of the works of the literary critics revealed that five major traditions have conceptualized the ghazels: mystical, Khayyamian, historical-political, romantic, and antihypocritical (Shamisa, Estelami). The idea of stratified lines of reading in interpretive traditions, of course, only paves the way for more comprehensive investigations into criticism and translation. One interesting topic for further scrutiny is the way lingual aesthetics and poetic considerations are framed in a translation. It was clarified in this study that two translations may fall under the same interpretive tradition although they may employ very different modes of formal representation. For instance, although the versions rendered by Clarke, Bicknell, and Avery and Heath-Stubbs could 
be regarded as "mystical" readings, their methods of literary configuration are markedly different. Clarke's translation appears to be an "imitated" version of the Persian ghazel scheme; Bicknell and Avery and Heath-Stubbs rely on paratextual notes to further supplement the content they translate. Such translational variability in form (along with narrative selectivity) could only be explained when theories of interpretation are integrated into those of poetics.

In a paper concerned with the translation of poetic films, Șerban addresses several issues such as hermeneutics, silence, ideology, and aesthetics; what is important from a poetic viewpoint is the quality of word choice in translated poetic films: "[q]uantity is no guarantee of quality and depth, and it can generate noise that can very often be non-communication in disguise" (Șerban 261). In a similar study, Kohlmayer emphasizes the effect of rhetoric in literary translation, criticizing theories such as text linguistics that have ignored the "acoustic potential" in the literary work (235). A researcher, for instance, may want to probe into how translators respond to the poetic judgments of metatexts while considering questions of interpretation. Are the translations following a particular tradition (e.g. romantic in Hafezian translations) more stylized in terms of prosody? More fundamentally, is there a relationship between tradition and poetics?

\section{Works Cited}

Arberry, Arthur, J. Fifty Poems of Hafiz. Cambridge UP, 1974.

Atherton, Carol. Defining Literary Criticism Scholarship: Authority and the Possession of Literary Knowledge, 1880-2002. Palgrave Macmillan, 2005.

Avery, Peter, and John Heath-Stubbs. Thirty Poems. Butler and Tanner, Ltd, 1952.

Bassnett, Susan, and Peter Bush. The Translator as Writer. Continuum, 2007.

Bassnett, Susan. "The Figure of the Translator." Journal of World Literature, vol. 1, 2016, pp. 299315, doi: 10.1163/24056480-00103002.

Bassnett, Susan. Translation: The New Critical Idiom. Routledge, 2014.

Bicknell, Herman. Háfiž of Shíráz: Selections from His Poems. Harvard University Library, 1875. 
Cercel, Larisa, et al. "Hermeneutics as a Research Paradigm." Translational Hermeneutics: The First Symposium, edited by Radegundis Stolze, John Stanley, and Larisa Cercel, Zeta Books, 2015, pp.17-40.

Clarke, Henry Wilberforce. English Translation of the Divan of Hafez. Edited by Behrouz Homayoun Far, vol. 1.03, Ibex publishers, 2001.

Dargahi, Mahmood. "The Foundations of Hafez Thought" [In Persian]. Kavoshnameh, Journal of Research in Persian Literature and Language, vol. 10, no. 18, 2009, pp. 225-42.

Dostal, Robert, J. The Cambridge Companion to Gadamer. Cambridge UP, 2002.

Estelami, Mohammad. A Course on Hafez: Commentary and Explication of Hafez's Ghazels [In Persian], vol. 1, Sokhan Publication, 2009.

Fitch, Brian T. "Literary Criticism as Translation: The Status of the Metatext." Miscellanea 3, EUT Edizioni Università di Trieste, 1996, pp. 23-33.

Gadamer, Hans-Georg. Philosophical Hermeneutics. Translated and edited by David E. Linge, University of California Press, 1977.

Gadamer, Hans-Georg. Truth and Method. 1960. Translated by Joel Weinsheimer and Donald G. Marshal, Continuum, 2004.

García, Adolfo Martín. "The Circumscribed Infinites Scheme (CIS): A Deconstructive Approach to Translating Poetry." Target, vol. 20, no 1, 2008, pp. 115-34, doi: 10.1075/target.20.1.07mar.

Genette, Gérard. Palimpsests: Literature in the Second Degree. Translated by Channa Newman and Claude Doubinsky, University of Nebraska Press, 1982.

Habib, M.A.R. A History of Literary Criticism: From Plato to the Present. Blackwell Publishing, 2005.

Hüsgen, Thomas J. C. "Literarische Übersetzungskritik und Hermeneutik." Philosophy and Practice in Translational Hermeneutics, edited by John Stanley, Brian O'Keeffe, Radegundis Stolze, and Larisa Cercel, Zeta Books, 2018, pp. 319-37. 
Jafari-Langroudi, Mohammad Jafar. Hafez and Iran's Survival [In Persian]. Ganj-e Danesh Publishing, 1989.

Kennedy, George A. The Cambridge History of Literary Criticism: Volume 1: Classical Criticism. Cambridge UP, 2008.

Kharmandar, Mohammad Ali. "Ricoeur's Extended Hermeneutic Translation Theory: Metaphysics, Narrative, Ethics, Politics." Études Ricoeuriennes / Ricoeur Studies, vol. 6, no. 1, 2015, pp. 73-93, doi.org/10.5195/errs.2015.281.

Kharmandar, Mohammad Ali. "The Strata of Subcultural Translation: Sources of Fragmentation in Globalizing Societies." Redefining Translation and Interpretation in Cultural Evolution, edited by Olaf-Immanuel Seel, IGI Global, 2018, pp. 142-60, doi: 10.4018/978-1-5225-2832-6.ch008.

Kohlmayer, Rainer. "Die Stimme im Text als tertium comparationis beim Literaturübersetzen.” Translational Hermeneutics: The First Symposium, edited by Radegundis Stolze, John Stanley, and Larisa Cercel, Zeta Books, 2015, pp. 235-57.

Kolbas, E Dean. Critical Theory and the Literary Canon. Westview Press, 2001.

Mueller-Vollmer, Kurt. The Hermeneutics Reader. Continuum, 2006.

Osimo, Bruno. "Meaning in Translation: A Model Based on Translation Shifts." Linguistica Antverpiensia, New series, Themes in Translation Studies, vol. 7, pp. 209-26.

Popovič, Anton. "Aspects of Metatext." Canadian Review of Comparative Literature, 1976, pp. 22535.

Ricoeur, Paul. Memory, History, Forgetting. Translated by Kathleen Blamey and David Pellauer, University of Chicago Press, 2004.

Ricoeur, Paul. Time and Narrative (Volume 1). Translated by K. McLaghlin and David Pellauer, University of Chicago Press, 1984.

Sattari, Jalal. An Introduction to Mystical Symbolism [In Persian]. Markaz Publishing 1993.

Șerban, Adriana. "Writing, Directing and Translating Poetic Films." Translational Hermeneutics: 
The First Symposium, edited by Radegundis Stolze, John Stanley, and Larisa Cercel, Zeta Books, 2015, pp. 259-88.

Shahriari, Shahriar. "Ghazal 1." Hafiz-e Shirazi, 9 Apr. 1999, www.hafizonlove.com/divan/01/001.htm. 1999. Accessed 20 Jan. 2018.

Shamisa, Siroos. Notes on Hafez [In Persian]. Elm Publishing, 2009.

Stolze, Radegundis. "Dimensionen der Subjektivität beim Übersetzen." Philosophy and Practice in Translational Hermeneutics, edited by John Stanley, Brian O'Keeffe, Radegundis Stolze, and Larisa Cercel, Zeta Books, 2018, pp. 77-99. 
[1] In some theories of metatext, translation is seen as a "metatext" imitating a prototext (original). These theories concentrate on the "continuity" of (inter-)textual relations (Popovič 231-32). As an advocate of such theories, Osimo states that "[f]ollowing Popovič's and Lûdskanov's models, we can state that a translation process, starting from a prototext, produces a metatext (i.e. a naturally or directionally 'equivalent' text, if you will) minus an involuntary, necessary loss, plus an involuntary, necessary added meaning" (213). Given Genette's definition, a metatext and a translation are distinguished in the present study, as the former is seen as an exclusively critical reading rather than an imitative process.

\section{cc) (i) (9)}

Creative Commons Attribution-NonCommercial-NoDerivatives 4.0 International License 